\title{
CORRIGENDUM
}

\section{Newly identified variability in Brucella canis fatty acid content is associated with geographic origin - CORRIGENDUM}

\author{
A. BROWER, N. LUCERO, O. OKWUMABUA, K. K. GOPAUL, \\ A. M. WHATMORE, S. L. CRAVERO AND M. D. TRANGONI
}

doi: 10.1017/S0950268812001240, Published by Cambridge University Press, 13 July 2012.

In the article by A. Brower, N. Lucero, O. Okwumabua, K. K. Gopaul, A. M. Whatmore, S. L. Cravero and M. D. Trangoni

[1] there was an error in the listing of authors, with one author missing: P. Groussaud

The correct authorship is:

A. BROWER ${ }^{1 *}$, N. LUCERO ${ }^{2}$, O. OKWUMABUA ${ }^{3}$, P. GROUSSAUD ${ }^{4}$, K. K. GOPAUL ${ }^{4}$, A. M. WHATMORE $^{4}$, S. L. CRAVERO ${ }^{5}$ AND M. D. TRANGONI ${ }^{5}$

${ }^{1}$ University of Nottingham, School of Veterinary Medicine and Science, Loughborough, UK

${ }^{2}$ ANLIS, Brucellosis Service, Buenos Aires, Argentina

${ }^{3}$ University of Wisconsin, School of Veterinary Medicine, Wisconsin, USA

${ }^{4}$ Animal Health \& Veterinary Laboratories Agency, Department of Bacteriology, Surrey, UK

${ }^{5}$ Instituto de Biotecnología, INTA-Castelar, Buenos Aires, Argentina

\section{REFERENCE}

1. Brower A, Lucero N, Okwumabua O, Gopaul KK, Whatmore AM, Cravero SL, Trangoni MD. Newly identified variability in Brucella canis fatty acid content is associated with geographic origin. Epidemiology and Infection. Published by Cambridge University Press, 13 July 2012. doi:10.1017/S0950268812001240. 